\title{
Application and Development of Automobile New Media Operation under Data Service
}

\author{
Juan Kong ${ }^{1}$ and Xiang $\mathrm{Li}^{2}$ \\ No.1111, Huchenghuan Rd, Pudong,Shanghai, P.R.China 201306 \\ Shanghai Jian Qiao University \\ 15054@gench.edu.cn,715130080@qq.com
}

\section{Keywords: Automotive; New media; Marketing}

\begin{abstract}
With the rise of emerging media technologies, the development of computer network technologies and the rapid development of mobile communication technologies, the emerging media is bred in a new development environment and the range of brand marketing applications is also expanding. The automotive industry has long been known for its implementation of brand promotion through the use of new media sales. In this paper, a variety of new media operation modes frequently used in the automobile industry are taken as research objects, analyzes the forms, characteristics, As well as its existing problems, puts forward a series of improvement and optimization tactics aimed at the shortage of new media.
\end{abstract}

\section{Introduction}

Car companies have built their own strong sales systems in the face of fierce competition worldwide. Although the sales system of each automobile enterprise has its own different operation mode and characteristics, after several decades of development, the sales system of each automobile enterprise has matured and has many common features, which are common to the modern automobile sales system in the world. The fundamental model laid the foundation. The combination of production and marketing, sales and marketing, production and marketing of three ways has combined to form a car marketing system, these three types of ways have their own advantages. Due to the different realities of manufacturers and their level of development, the systems they choose will differ. At present, the combination of production and sales is a universal sales system in the world and has also become the main form of development of foreign automobile enterprises.

\section{The Connotation of New Media Marketing}

New media marketing is about selling brands using the Internet, mobile phones and other interactive methods.[1][2] This is to use the existing Internet, mobile phone or other media that can interact with each other and use the interactivity of these media to assist the sales business.

The biggest difference between this form and traditional marketing form is that marketing media is different. Different from the popular media such as newspapers, periodicals, radio and television used in the past sales, the new media marketing uses networks and mobile phones that can search for addresses, have stronger activities and make it easier to track sales dynamically media.

Third, Analysis of the current situation of automobile new media marketing

Under the new media environment, the development trend of China's auto market is mainly manifested in the following aspects:

The Recovery in the Growth of Automobile Production and Sales. According to the data of China Association of Automobile Manufacturers, the following is the statistics of China's automobile production and sales from 2011 to 2014: 
Table 1 China 2011-2014 car sales statistics

\begin{tabular}{|l|l|l|l|l|}
\hline \multicolumn{1}{|c|}{ years } & $\begin{array}{l}\text { Production (ten } \\
\text { thousand) }\end{array}$ & $\begin{array}{c}\text { Output } \\
\text { increased year } \\
\text { on year }(\%)\end{array}$ & $\begin{array}{c}\text { Sales (ten } \\
\text { thousand) }\end{array}$ & $\begin{array}{l}\text { Sales increased } \\
\text { year on year(\%) }\end{array}$ \\
\hline 2011 & 1841.89 & --- & 1850.51 & --- \\
\hline 2012 & 1927.18 & $4.63 \%$ & 1930.64 & $4.33 \%$ \\
\hline 2013 & 2211.68 & $14.7 \%$ & 2198.41 & $13.87 \%$ \\
\hline 2014 & 2373.16 & $7.3 \%$ & 2349.90 & $6.89 \%$ \\
\hline
\end{tabular}

(Source: The data comes from China Association of Automobile Manufacturers data statistics)

Table 1 Data analysis shows that in 2014 China's automobile production and sales volume increased by $7.3 \%$ and $6.89 \%$ over 2013 ; China's automobile production and sales for the whole year of 2013 increased by $14.7 \%$ and $13.87 \%$ respectively over 2012, showing a rapid increase improve. The production and sales volume of China's automobiles have shifted from the "slow growth" period in 2011 and 2014 to the rapid growth period.

Mobile Internet Trends. By the end of 2013, China had more than 6 billion Internet users, 244 million Internet users had paid online, and 79.11 million users had already paid for mobile phone networks. The rapid growth of mobile networks and the rapid increase in the number of online payment users of mobile phones have provided new opportunities for the development of automobile companies.

Service-oriented Market Trends. The automobile industry is in the transitional period from the introduction period to the popularity period. Objectively speaking, the automobile sales are transformed from resource-based to service-oriented. In the context of new media operations, buyers are able to deliver industry news on a large scale, quickly and at low cost via new media, greatly increasing their initiative and market position and highlighting the significant role of automotive operations services.

\section{Problems Existing in New Media Marketing of Automobiles}

There is a Lack of Overall New Media Marketing Plan. Although the new media marketing has achieved some results, the auto market generally outsources its businesses to many specialized companies when it launches new media marketing, seldom considers the characteristics and needs of new media sales.[3] Therefore, on the whole, Although the sales model diversified, but still fragmented. In addition, the lack of co-ordination plan, the implementation of new media sales also face many problems, such as the lack of division of tasks, and difficult to take advantage of the combination with the offline resources (such as $4 \mathrm{~S}$ shops, car showrooms), did not play its full role.

There is a Lack of Clear and Reliable Quantitative Evaluation of Marketing Process and Marketing Performance. In the present situation, there is a lack of a strong appraisal of sales process and sales performance, or only the technical standard, neglect of the return of investment and other feedback on sales performance. There are still some car companies that do not care about collecting quantitative data when they launch new media sales. In fact, these data are very important for the enterprise. Enterprises can track these data and then find the problems in the sales process, and thus propose appropriate solutions to real-time increase the overall operational effectiveness of enterprises. In addition, through the overall analysis of the collected data, customers can be analyzed in the consumption process, the actual effect after the sale, etc., to guide the next phase similar to the development of sales activities. Without focus on real-time tracking and analysis of quantitative standards, its advantages can not be fully recognized in the emerging new media operations, and the operation of the car sales market does not improve the cost of sales.

There is a Lack of Sophistication in New Media Marketing Techniques and Tools. Mainly in the absence of data planning, registration procedures for some sites is very complicated, registration information requirements are exhaustive, but for the user's information can not be fully utilized.This 
not only affects the user experience, but also causes a lot of users to give up the registration, which makes the website registration rate very low; there is also a misunderstanding in the construction of the site, think that as long as the website set up good future, there will be a user use, without the Internet search engine function to the limit, also ignore the use of the network Advertising, search keywords and other means to fully expand the promotion of the site, resulting in the site's click-through rate is not high, can not get the sales effect; or the lack of practical content online, or the lack of innovative forms of site, or the lack of personalized Created to allow customers to stay on the page for a very short period of time, which is not available sales.

\section{Optimization Strategy for New Media Marketing of Automobiles}

Sales Guide Optimization Strategy. The sales guidance strategy based on new media marketing mainly includes these strategies: a) Fully understand the preferences of the customers, and achieve the effect of rapid proliferation by adopting the ways in which customers can accept, incorporate the products sold and related information into entertainment and interactive platforms; b) By creating elaborate rules, it provides sufficient convenience to resolve customers' purchase intention, buying time, buying a car budget, etc., and leads the prospective customers to the $4 \mathrm{~S}$ store; c) $4 \mathrm{~S}$ shop face to face with customers to provide quality services to customers, including detailed vehicle conditions introduced to customers, and to provide customers with test drive services to allow customers to fully experience the fun of driving; d) Conduct interactive and prized activities to encourage customers to release their trial-and-test driving experience to forums or designated activity areas for a certain amount of rewards, or obtain customer consent to release customer information onto the Internet, This can attract more customers; e) Maintaining good and long-term relationship with customers. With the consent of the clients, they often keep in touch with customers by phone or email, track the customers' buying intention, buying time and buying a car Changes, the implementation of change.[4] New media sales approach to the sale of the Internet offline customer touch points join together, and the use of new media sales integration of all car sales process, not only to promote or achieve sales, but also through the Internet with the customer a variety of network Way to exchange some of the information needed by the business, such as customer needs, purchases and other collected for auto companies to analyze, to improve their own problems.

Marketing Process and Performance Optimization Strategy. Measurability is one of the biggest advantages of new media sales compared to traditional sales, so car companies must consider the digital ways it involves data sales, not only in terms of features and usage, but also in their quantification project. Mainly reflected in the four aspects, the effectiveness of online advertising measurement, marketing website effectiveness measurement, Email Marketing effectiveness measurement and microblogging marketing effectiveness measurement.

Maintaining and Developing Customer Relationships. Customer relationship management is a continuous process of continuously enhancing communication with customers, keeping abreast of customer needs, and continuing to reform and upgrade products and services so as to satisfy customers' requirements. As a result, some companies are starting to try to build a CRM approach using customers as a guide and using the preferences of netizens as a basis. In the automotive industry, all enterprises attach great importance to CRM, and they are in the process of transformation from a "product-centric" model to a "customer-centric" model. Truly meet the needs of customers and get recognized from Customer satisfaction needs to be met to start to improve customer loyalty and retention.[5]Customer information is the company's core and important information, many of the automotive industry giant companies have now begun to change their own ideas, try new ways to maintain the relationship with customers. And take a creative and interactive way, so that buyers actively involved in the research and development of the cargo, pay attention to the individual needs of buyers, to express their own needs for the brand.

Brand Building Optimization Strategy. Brand building is the core of each company sales, but also an important part of corporate brand delivery process. Throughout the sales process, the fundamental purpose is to promote the brand concept, enhance brand awareness, but also to show 
customers the spirit of the brand and the corporate culture. The fundamental, the entire process requires the participation of customers, but also to obtain customer approval. Hope that through the active participation of customers, and customers can achieve the effect of two-way communication, companies can also access customer ideas in a timely manner, but also through the participation of consumers play a role in spreading its own brand, enhance corporate brand value.

\section{Summary}

Buyers have become the main body of this era, car sales also need to proceed from the needs of buyers, car companies no matter what kind of sales methods, must proceed from the interests of buyers, which has become the development needs of the times. New media marketing for car dealers has become an important part of the whole industrial chain layout, which in turn can lay out auto finance and after-sales services. With the downstream flow of new media data in the industrial chain, core data processing capabilities will continue Be enhanced.

At the same time, the joint use of various sales methods to maintain the car sales in a benign direction, but also enable the company to obtain favorable help in the fierce market competition, only in this way, China's automobile industry can access the development of the market, welcome to purchase, to win their own sustainable development.

\section{Acknowledgements}

Project Fund from Shanghai University Young Teacher Training Subsidy Program (AAYQ1626).

\section{References}

[1] H.X. Wang:Based on the new media vehicle marketing model [J]. Auto Time, 2016. (In Chinese)

[2] S.S.Jiang:Based on the new media vehicle marketing model [J] Science and Technology Outlook, 2016, (26): 243. (In Chinese)

[3] X.F.Gai and X.F.Xie. Research on the Interactive Relationship between New Energy Vehicle Industry and Mass Media [J] .Science and Management, 2016. (In Chinese)

[4] P.Zhang. Science and technology books new media marketing initiatives [J]. Modern Marketing (late issue), 2015. (In Chinese)

[5] Fu Yatong. Leap from "traditional media" to "new media" - Exploration of all-media marketing of Qilu Evening Post Automotive Center [J]. Youth Press, 2015. (In Chinese)

[6] S.L. Lin and Y. Li. Sina microblogging car brand fans influence factors of empirical research [J]. Press University Press, 2015. (In Chinese) 